\title{
Of Spectralities and Afterlives in Philippine Cinema
}

Joseph Palis

The emergence of the moving image in early cinematographic experiments has led to the valorization of uniqueness and the eventual accordance of importance to cultural/aesthetic differences in these filmic works. Thomas Edison's actualities in the late 1890s somehow became the moving versions of daguerreotypes that also illustrated the late arrival of American imperialism in the Pacific. Early Filipinos depicted in three of Edison's actualities were portrayed by African American soldiers based in New Jersey (Feng , 2002; Palis, 2009). Edison's first representations of "Filipinos" in these 1899 actualities portrayed none too subtly what is essentially manifest destiny (Filipino soldiers were shown being pushed out of the frame by American forces with their horses and flag in tow). Can we ascribe a particular nationality to cinematic works emanating from these specific geographical spaces? In retrospect, can these actualities qualify as the first Filipino films even if the definition of who is and was a Filipino was calibrated differently at the time? With the advent of sound as a technological given in film production after 1927, some scholars thought that a cinematic bildungsroman had become possible, as the movies started speaking. Others counterclaim that the use of language in talking pictures should not signal the birth of a national cinema; rather, one should also be cognizant of the multitude of languages and ethnolinguistic articulations that are being spoken and practiced by a nation's inhabitants. Still others argue that the concept of nation was not understood quite the same way then as it is currently perceived and conceived.

In Patrick F. Campos's carefully written, assiduously researched and well-argued book, the auteurial, regional, geographical, diasporic, folkloric and more-than-human aspects that constitute, influence, and impact the creation of films and the filmmaking practices in the Philippines reveal a 'national cinema' that moves and flows with the tidalectics of the archipelago. Alert to the nexus of globalization, diaspora and digital technology, Campos (2016) acknowledges that:

Historical-cultural crossings, state intervention, and the demands of commercial filmmaking have linked national cinemas with forces and causes beyond national borders. (p. 3)

The national is framed in international lenses. It is also a reflection of the global consumption and fetish for the authentic and unalloyed "national" products such as filmic works. The acceptance and standardization of 
the mechanical production undertaken to create and process a film into a commodity also contributes to this demand. Is the current national cinemascape dictated by global corporations and capital?

If Kenichi Ohmae's (1996) assertion is that "region states" reconfigure the global logic by being linked to contiguous region states because of emerging markets, rather than their own "host" nations, what becomes of the specific geographies that are in the peripheries? What becomes of native films and filmmaking that do not subscribe to the current hegemonic practices? Will there be a recuperation of an 'art-naif' in the cultural and economic logics of late capitalism? How will Kadu from Turumba (1981) make sense of an even larger demand for the hand-painted papier mache animals produced in his village?

Chris Lukinbeal (2005) has argued that landscapes portrayed in films can be seen as metaphor, theater and spectacle. Alert to the regimes of power that underline ideology and agency in the actual placements of objects and people in a cinematic frame, Lukinbeal asserts that people and places not only function as the film's landscapes, they are also a compass, situating the story so the film audience can be guided and adequately situated. Following this argument, Campos's rich re-reading of Ishmael Bernal's Manila By Night (1980) in the book's first chapter uses a compass that resists the magnetic fields of the Marcoses' modernization of Metro Manila and the mythic idealism of a new society. In order to tell the story of the ordinary citizens' right to the city, Campos employed Edward Soja's thirdspace (following Lefebvre's [1968] triad in spatial configurations) to render Metro Manila as a space of alterity, liminality and contestation and the opening up of new alternatives. Indeed the idealization of the Marcoses' drive for 'national development' that erases spaces of filth, poverty and marginality, finds a cinematic lived experience counterpart in Manila By Night (as well as in Lino Brocka's Manila in the Claws of Light, 1975), characterized by urban filth, violence and mayhem. More than Soja, I think David Harvey's reworking of Lefebvre's concept of the right to the city presents an even more appropriate and compelling continuum that radicalizes the lived spaces of the City of Man (Harvey, 2008). Harvey offers the following:

The right to the city is far more than the individual liberty to access urban resources: it is a right to change ourselves by changing the city... The freedom to make and remake our cities and ourselves is, I want to argue, one of the most precious yet most neglected of our human rights. (p. 23)

Harvey's (2008) version of right to the city is promoting class struggles in given territories and grassroots-based movements that provide spaces 
for anti-capitalist transformations. The open-ended fate of Alex in the conclusion of Manila By Night can be read as the singular birth of a resurgent nationalist whose right to the city promises radical becomings.

Campos's (2016) discussion on rural landscapes in Chapter 9 engagingly deploys the humanist geography through $\mathrm{Yi}-\mathrm{Fu}$ Tuan in plotting "the movement of cinematic imaging of the rural from clearing space to making place" (p. 349). The encryption of affect and meaning on 'place' bestows it with a range of culture-specific attributions that make 'rural' a much more nuanced concept than just a land use typology. Noting that "the first 'native' film is a rural film” (p. 351) in citing Jose Nepomuceno's Dalagang Bukid [Country Maiden](1919), Campos convincingly argues that pre-war (and early postwar) rural films' portrayal are influenced historically by prevailing cultural logic. Campos, more importantly writes that depicted ruralities simultaneously signify a nostalgia for the "Golden Age of a bygone era" and steadfastly refuse the cinematic portrayal of rural space as pastoral, opting instead to depict rurality as "defiled, defamed, and defaced" (p. 359). Rural geographer Paul Cloke (1999) once said that what makes a non-urban space important in human geography is a combination of the

...idyll-ized imagined geographies peddled by media and advertising and held by people as significant reference maps for spatial behavior, and the specific material changes occurring in rural geographical areas. (p. 257)

While much has been written about the commodification of nature and rural space and how it is being tied up to consumption, perhaps another question needs to be asked: what will happen to the site of the rural as a discursive space for contestation and liminality when the binarism of urban and rural is no longer a relevant geographical concern? Will there be a growth of peri-urban and peri-rural areas that accommodate the qualities of both? Will the tradition of rural filmmaking and the semantic emplacement of the rural change the dynamics of cinematic mapping? What cartographic lenses will be used? How will (new) meanings be negotiated? Will a haunting of the rural surface in the Filipino cinematic frames? In the recently concluded and inaugural To Farm Film Festival 2017, the harvest of film entries range from the rice landscapes of Pitong Kabang Palay [Seven Cavans of Rice] (2016) to Pauwi Na [Going Home] (2016). While Pitong Kabang Palay problematizes domestic food shortage in the countryside, Pauwi $\mathrm{Na}$ is essentially a road movie from the urban to the rural periphery that somehow collapses the two. It is most likely emblematic of a new breed of film that avoids situating itself in the traditional notion of rural space, 
and instead imagines being in-transit and in-between places as a way to reconceptualize the two geographical land uses as mutually constitutive and not having Manichaean distinctions. Rurality is now a specter abetted by constant human mobility.

Perhaps it is in the chapter entitled "Ghostly Allegories" that spectrality is most apparent. While Campos utilizes a number of horror films such as Sigaw [The Echo] (2004) and The Maid (2005) to investigate different allegories emanating from the historical to diasporic spaces, it is the iteration that the hauntings in films are merely rehearsals for the re-invocation of abuses and transgressions emanating from our colonial history that drives home the point most effectively. Citing Pheng Cheah's notion of spectral nationality, I argue that other non-genre horror films such as Lav Diaz's Batang West Side [West Side Avenue] (2001), Sari Dalena and Keith Sicat's Rigodon (2005) and Neill Dela Llana and Ian Gamazon's Cavite (2005) are good if non-obvious case studies to explain spectralities. These films verge on national hauntologies as the subject formations of Filipinos are constantly taken apart, made and re-made. From the diasporic Filipinos in post-911 New Jersey and New York to a Filipino American visiting Cavite for the first time, these characters' respective ghosts constantly hover over them. In the words of Julian Wolfrey (as cited by Colin Davis, 2005):

"[A]ll forms of narrative are spectral to some extent," and "the spectral is at the heart of any narrative of the modern"; moreover, "to tell a story is always to invoke ghosts, to open a space through which something other returns," so that "all stories are, more or less, ghost stories." (p. 378)

If cinemas' narratives are all ghost stories where the haunting of various histories, uneven spatial stories, and non-linear cartographic films are both present and absent, what is the afterlife of Philippine cinema? Can a national cinema thrive when lines are constantly redrawn and reconfigured, and where lived places shift constantly to accommodate new(er) stories and narratives? One wonders what ever happened to Kadu, or more importantly, what did he become? Campos's book offers various routes and cardinal points to find one's way in the complexity of cinema in and of the Philippines. 


\section{References}

Campos, P. F. (2016). The end of national cinema: Filipino film at the turn of the century. Diliman: University of the Philippines Press.

Cloke, P. (1999). The country. In P. Cloke, P. Crang \& M. Goodwin (Eds.), Human Geographies, (pp. 256-266). London: Arnold.

Davis, C. (2005). Hauntology, spectres and phantoms. French Studies, 59(3), 373-379.

Feng, P. (2002). Identities in motion: Asian American film and video. Durham: Duke University Press.

Harvey, D. (2008). The right to the city. New Left Review, 53, 23-40.

Lefebvre, H. (1968). Le droit à la ville. Paris: Anthropos.

Lukinbeal, C. (2005). Cinematic landscapes. Journal of Cultural Geography, 23(1), 3-22.

Ohmae, K. (1995). The end of the nation state: the rise of the regional economies. New York: Free Press.

Palis, J. (2009). The ethnographic spectacle of the 'other' Filipinos in early cinema. GeoJournal, 74(3), 227234.

JOSEPHPALIS is an assistant professor at the Department of Geography at the University of the Philippines, Diliman. He is currently a co-editor of the Pivot Series of Palgrave-Macmillan focused on Geographies of Media. He teaches graduate classes in countercartographies, cultural geography, cinematic geographies/ cartographic cinema and spatial humanities. He is a member of the American Association of Geographers and the Philippine Geographical Society (corresponding author: josephpalis@gmail.com). 
